\title{
Evaluating different interrow distance between corn and soybean for optimum growth, production and nutritive value of intercropped forages
}

\author{
Jeongtae Kim ${ }^{1}$, Yowook Song ${ }^{1}$, Dong Woo Kim ${ }^{1}$, Muhammad Fiaz ${ }^{2}$ and Chan Ho Kwon ${ }^{1 *}$ (D)
}

\begin{abstract}
Background: Maize fodder is being used as staple feed for livestock but it lacks protein and essential amino acids; lysine and tryptophan. Intercropping maize with leguminous soybean crop is promising technique under limited land resources of South Korea but it can only give considerable advantages when adequate distance is provided between corn and soybean rows. Main aim of present study was to find-out adequate distance between corn and soybean seeding rows for optimum growth, yield and nutritive value of intercropped forage.
\end{abstract}

Methods: Different interrow distances between corn and soybean were evaluated under four treatments, viz. 1) Corn sole as positive control treatment 2) Zero $\mathrm{cm}$ between corn and soybean (control); 2) Five $\mathrm{cm}$ between corn and soybean; 3) $10 \mathrm{~cm}$ between corn and soybean, with three replicates under randomized block design.

Results: Findings depicted that height and number of corn stalks and ears were similar $(P>0.05)$ among different treatments. Numerically average corn ear height was decreased at zero $\mathrm{cm}$ distance. Dry matter percentage in all components; corn stalk, corn ear and soybean was also found not different $(P>0.05)$ but dry matter yield in component of corn ear was lower $(P<0.05)$ at zero $\mathrm{cm}$ distance as compared to that of 5 and $10 \mathrm{~cm}$ interrow distances. In case of nutritive value, total digestible nutrient yield in intercropped corn was also found lower $(P<0.05)$ at zero $\mathrm{cm}$ distance than that of 5 and $10 \mathrm{~cm}$ interrow distances between corn and soybean seeding rows. Substantial decrease in dry matter yield of maize ear at zero $\mathrm{cm}$ distance might be attributed to factor of closed interrow spacing which made interplant competition more intensified for light interception, necessary for photosynthetic activity. Lower dry matter yield in ear also reduced total digestible nutrients in intercropped maize because it was determining factor in calculation of digestible nutrients. The optimum yield and nutritive value of forage at wider interrow distance i.e. $5 \mathrm{~cm}$ between corn and soybean might be due to adequate interseed distance.

Conclusion: Conclusively, pattern of corn and soybean seeding in rows at $5 \mathrm{~cm}$ distance was found suitable which provided adequate interrow distance to maintain enough mutual cooperation and decreased competition between both species for optimum production performance and nutritive value of intercropped forage.

Keywords: Interrow distance, Seeding rows, Corn-soybean and intercropping forage

\footnotetext{
* Correspondence: chkwon@knu.ac.kr

'Department of Animal Science, Kyungpook National University, 2559,

Gyeongsang-daero, Sangj-si 37224, South Korea

Full list of author information is available at the end of the article
} 


\section{Background}

In connection to achievement of high economic growth in Republic of Korea, consumption pattern is massively shifted towards meat and dairy products. Accordingly, role of livestock industry has become more prominent as an attempt to meet increasing domestic demand. Therefore, livestock production reaches $40.2 \%$ of total Agro-forestry production $[1,2]$. Consequently, livestock population of beef cattle, pigs, chicken, ducks and dairy cattle is reached to $2742,10,355,101,014,10,705$ and 402 thousand heads, respectively during second quarter of year 2016 [3]. This considerable number of livestock requires ample amount of feeding resources in country through import or local production. Unfortunately, selfsufficiency in production of feeding resources for livestock is quite low due to limited cultivatable land and use of traditional cropping techniques.

Maize is worldwide renowned as king of cereal fodders which can be used as major feed ingredient in livestock. It is good source of carbohydrates and provides $60 \%$ energy and 90\% starch in animal's diet [4]. Farmers prefer to cultivate maize as staple feed for their animals because it can be easily processed and preserved for silage. However, maize forage lacks protein and essential amino acids; lysine and tryptophan [5]. Legumes are known to be an excellent source of protein and might be used to cover protein deficiency of cereals [6]. In attempt to improve the nutritive value of maize, intercropping maize with soybean is getting recognized in Republic of Korea by farmers as a promising technique under limited land resources [7]. Mixture of nitrogen fixing leguminous and none fixing cereal crop would gave more productivity than mono-cropping [8] through biculture rhizobial symbiosis [9]. Intercropped legumes can fix nitrogen from atmosphere and do not compete with companion maize crop for nitrogen resources [10] making cereal legume biculture system more superior than monocropping [11].

Main aim of intercropping strategy has been to utilize resources such as distance, light and nutrients efficiently [12] for enhancing forage quality as well as quantity [13]. When two independent crops are grown together, plants of each component need enough distance in facilitating cooperation and competition between crops. Adequate interseed distance is quite important to be considered in preliminary spatial arrangements because spatial arrangement are determining factor for optimum productivity in corn-soybean intercropping [14]. Any change in hierarchy and spatial pattern can greatly influence productivity of intercropping strategy [15]. The literature regarding optimum interseed distance between corn (Zee mays L.) and soybean (Glycine max L.) rows in intercropping system under Korean environment conditions is scanty. Therefore present study was designed with main objective to find-out adequate distance between corn and soybean seeding rows for optimum growth, yield and nutritive value of intercropped forage.

\section{Methods \\ Location of research site}

Research trial was conducted at private farm in Angangeup of Gyeongju city in Gyeongbuk province of South Korea. Its geographical coordinates are $36^{\circ} 00^{\prime} 51.5^{\prime \prime} \mathrm{N}$ $129^{\circ} 12^{\prime} 13.5^{\prime \prime} \mathrm{E}$. The comparative average temperature and total rainfall recorded during study period and last five years is given in Table 1.

\section{Experimental treatments and design}

Different interseed distances between corn and soybean seeding rows were evaluated under three research treatments, viz. 1) corn sole seeding (positive control), 2) zero $\mathrm{cm}$ distance between corn and soybean seeding rows (control), 3) five $\mathrm{cm}$ distance between corn and soybean seeding rows and 4) ten $\mathrm{cm}$ distance between corn and soybean seeding rows. Each treatment was replicated three times following randomized block design.

An area of land having length and width measurement $(15 \times 12 \mathrm{~m})$ was selected and preliminary divided it equally into 3 main blocks (replicates); A, B and C. Then each block was further divided into 4 plots. Each plot had length and width $(5 \times 3 \mathrm{~m})$. Finally, 12 plots were made available for random application of four treatments with three replicates.

\section{Seed and seeding}

In connection with corn soybean intercropping, maize (variety named Pioneer P1184) and soybean (crossbred variety named PI483463 $\times$ Hutcheson) were sown on 15 th June of 2015, whereas harvesting was furnished on 8th October of same year. The land was prepared with application of fertilizer NPK $(21: 17: 17)$ at the rate of $200 \mathrm{~kg}$ per hectare.

Preliminary, seeding of corn was accomplished on equally distant 4 lines in each plot. In case of positive control treatment for corn, soybean seeding was not performed leaving plots for corn mono-cropping. However, soybean seeding under 2nd treatment (control) was conducted over the same rows where corn seeding was done

Table 1 Comparative average temperature and total rainfall in Gyeongju city, Gyeongbuk

\begin{tabular}{llllll}
\hline Climate & Year & June & July & Aug & Sep \\
\hline Temp $\left({ }^{\circ} \mathrm{C}\right)$ & 2015 & 21.2 & 24.0 & 25.4 & 19.8 \\
& $2010-2014$ & 21.4 & 25.4 & 25.3 & 20.2 \\
Rainfall $(\mathrm{mm})$ & 2015 & 22.4 & 171.6 & 104.2 & 37.0 \\
& $2010-2014$ & 90.4 & 170.0 & 243.8 & 82.5 \\
\hline
\end{tabular}

Source: Korea Meteorological Administration, 2016 
Table 2 Effect of different interrow space between corn \& soybean on growth performance of forage

\begin{tabular}{lllll}
\hline Parameters (Mean \pm SE) & $\begin{array}{l}0 \mathrm{~cm} \text { Corn sole } \\
\text { (Positive control) }\end{array}$ & $\begin{array}{l}0 \mathrm{~cm} \text { distance Corn } \\
\text { soybean (Control) }\end{array}$ & $\begin{array}{l}5 \mathrm{~cm} \text { distance } \\
\text { Corn soybean }\end{array}$ & $\begin{array}{l}10 \mathrm{~cm} \text { distance } \\
\text { Corn soybean }\end{array}$ \\
\hline Corn stalk height $(\mathrm{cm})$ & $250.4 \pm 4.8$ & $244.2 \pm 6.4$ & $260.8 \pm 4.8$ & $248.3 \pm 13.5$ \\
Corn ear height $(\mathrm{cm})$ & $75.5 \pm 4.2$ & $66.8 \pm 3.6$ & $74.2 \pm 1.2$ & $74.2 \pm 5.3$ \\
Soybean height $(\mathrm{cm})$ & - & $46.2 \pm 6.1$ & $52.5 \pm 7.7$ & $45.4 \pm 2.1$ \\
Corn stalk number (No.) & $27.0 \pm 2.5$ & $27.6 \pm 1.4$ & $27.5 \pm 1.5$ & $28.0 \pm 0.5$ \\
Corn ear number (No.) & $26.6 \pm 1.3$ & $26.0 \pm 0.5$ & $26.0 \pm 2.0$ & $26.0 \pm 1.5$ \\
Soybean number (No.) & - & $49.3 \pm 4.2$ & $33.5 \pm 2.5$ & $46.0 \pm 7.0$ \\
Coupling (No.) & - & $18.0 \pm 1.5$ & $16.5 \pm 2.5$ & $15.3 \pm 0.6$ \\
\hline
\end{tabular}

Variables having no superscripts in the same row are not different $(P>0.05)$, SE Standard error

previously to ensure zero $\mathrm{cm}$ distance between corn and soybean seeds. Whereas, seeding of soybean under 3rd treatment was carried out on separate parallel rows which were $5 \mathrm{~cm}$ distant away from corn seeding lines. The same method was followed in 4th treatment but interseed distance was fixed $10 \mathrm{~cm}$ between corn and soybean rows.

Mixture of Alachlor and Pendimethalin herbicides was used after completion of seeding. The management and conditions like temperature, moisture, air and lighting were kept similar and identical to all experimental treatments.

\section{Data collection}

Height and number of maize stalk, maize ear and soybean was measured and counted on harvesting time. Maize height was taken from ground to top of plant and height of maize ear was measured from ground to the bud of ear evolved, whereas soybean height was measured from ground to top of plant. Five plants were taken randomly from each replicate for measuring data regarding height. Similarly, 2 samples from each replicate were randomly taken for dry matter and total digestible nutrient yield, initially weighed, dried in oven at $70{ }^{\circ} \mathrm{C}$ for $72 \mathrm{~h}$ and then again weighed after drying. The percentage of DM was just calculated using fresh yield and dry matter yield information. Total Digestible Nutrients (TDN) was calculated through following equation [16],

Total digestible nutrient $=(D M$ yield of maize stalk $\times$ $0.582)+($ DM yield of maize ear $\times 0.85)$.

Where, numbers 0.582 and 0.85 are constant factors used to calculate TDN.

\section{Parameters studied}

Effect of varying interrow spaces between corn and soybean was investigated in terms of following parameters, viz. corn stalk height and number, corn ear height and number, soybean height and number, coupling number, dry matter percentage, dry matter yield (corn stalk, ear and soybean) and total digestible nutrients yield (corn stalk plus ear).

\section{Statistical analysis}

Data were statistically analyzed using ANOVA technique under randomized block design through SAS 9.1.3 software. The difference among treatment means was tested

\section{Dry matter percentage}

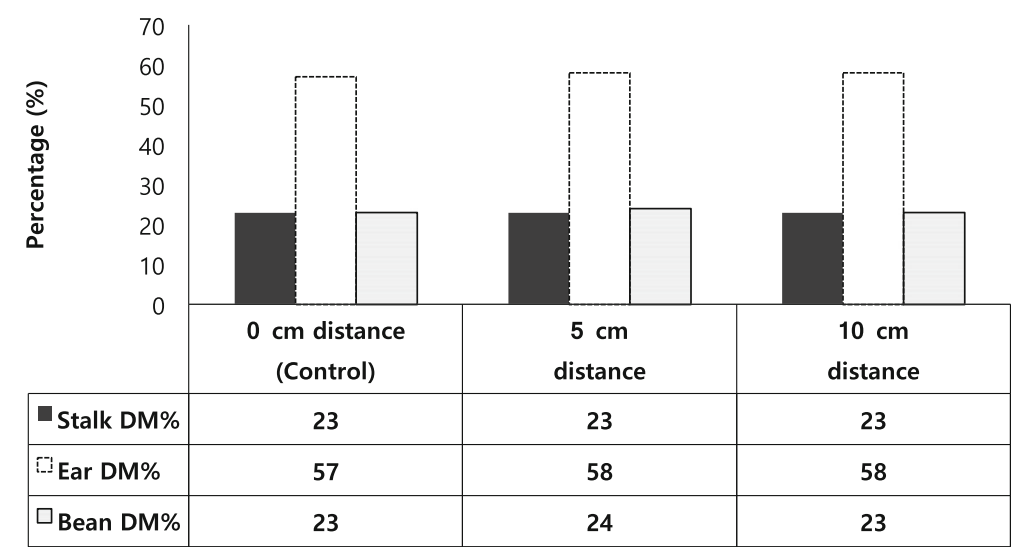

Fig. 1 Effect of different interrow distance between corn and soybean on dry matter percentage in corn stalk, corn ears and soybean components of mixed forage (Mean $\pm \mathrm{SE}$ ). *Same colored bar variable with value over top having no superscripts are not different $(P>0.05)$ 
through Duncan Multiple Range Test [17] and confidence level for this experiment was $95 \%$.

\section{Results \\ Effect of different interrow space between corn and soybean on growth performance of forage}

Response of interrow distance on growth performance of mixed forage is mentioned in Table 2. The height and number of corn stalks and ears were not significantly different $(P>0.05)$ among treatments of different interseed intervals. Similarly, soybean height, soybean number and corn soybean coupling were also not different among treatments. It was depicted that numerically average corn ear height was decreased at zero $\mathrm{cm}$ distance between corn and soybean seeding rows, although it was not significantly different from other treatments. In case of corn sole (Positive control treatment), the corn stalk height was not different $(P<0.05)$ with intercropping corn component at any interrow space but it was tended to high at $5 \mathrm{~cm}$ interrow distance between corn and soybean.

\section{Effect of different interrow space between corn and soybean on production of mixed forage}

Dry matter percentage (DM \%) in all components; corn stalk, corn ear and soybean was found not significantly different $(P>0.05)$ among inter-seed distances between corn and soybean seeding rows as shown by Fig. 1. Dry matter yield (tons/ha) in corn stalk and soybean components of intercropping forage was also not significantly different among treatments of different interrow distances. However, dry matter yield in component of corn ear was found lower $(P<0.05)$ at zero $\mathrm{cm}$ distance as compared to that of 5 and $10 \mathrm{~cm}$ interrow spaces as shown in Table 3. The DMY of corn component in corn sole was not different $(P<0.05)$ with intercropping corn component at any interrow space but it was tended to high at $5 \mathrm{~cm}$ interrow distance between corn and soybean. However, corn ear DMY was higher $(P<0.05)$ than that of zero $\mathrm{cm}$ treatment but not different $(P>0.05)$ with other treatments.

\section{Effect of different interrow space between corn and soybean on nutritive value of mixed forage}

Pattern of effect on nutritive value in terms of total digestible nutrients (TDN) yield was similar to that of dry matter yield as shown in Fig. 2. The TDN yield in component of corn (Stalk plus ear) was also found lower $(P<0.05)$ at zero $\mathrm{cm}$ distance than that of 5 and $10 \mathrm{~cm}$ interrow distances between corn and soybean.

\section{Discussion}

The substantial reduction in dry matter yield of intercropped maize ear at zero $\mathrm{cm}$ interrow distance between corn and soybean in present study might be attributed to factor of close interrow spacing which consequently affect interplant competition for light interception [18-20]. The light interception could be more available at wider interrow spacing than that of close interrow distance [20-22]. Intensified interplant competition for factor of light interception might influence dry matter yield of intercropped maize ears [23] because maize yield was linearly correlated with photosynthetic output [19]. If row spacing were increased in intercropping, photosynthetic activity of forage could be enhanced [24]. In connection to comparison of corn sole with other treatments, higher tendency of intercropping corn stalk height, corn stalk DMY and significantly higher intercropping corn ear DMY under $5 \mathrm{~cm}$ distance treatment might be due to suitable interrow space between corn and soybean seeding lines which could fetch optimum advantage of intercropping corn with soybean through efficient rhizobial symbiosis between two intercropped species [25].

Following pattern of dry matter yield in maize ear, TDN yield in intercropped corn forage was also comparatively lower $(P<0.05)$ at zero distance between corn and soybean seeding rows than that of wider interrow spacing. The possible reason might be lesser dry matter (DM) yield in maize ear as depicted by findings of this study. The DM yield of both components of intercropped maize forage; stalk and ear were determining factor of calculating its total digestible nutrient yield as mentioned in TDN formula. Better nutritive value of intercropped corn forage in terms of TDN at wider spaced $(5 \mathrm{~cm})$ seeding rows between corn and soybean might be due to adequate interseed space. Previously, Yang et al. (2016) also elaborated the influence of interrow space on yield of maize forage even in maize soybean relay strip intercropping system. In that study narrow-row spacing of maize ranged from 80 to $20 \mathrm{~cm}$ under relay strip intercropping, the yield of intercropped maize decreased by $25.53-3.13 \%$ [26].

Table 3 Effect of different interrow space between corn \& soybean on dry matter yield of forage

\begin{tabular}{lllll}
\hline Parameters (Mean \pm SE) & $\begin{array}{l}0 \mathrm{~cm} \text { distance Corn sole } \\
\text { (Positive control) }\end{array}$ & $\begin{array}{l}0 \mathrm{~cm} \text { distance Corn \& } \\
\text { soybean (Control) }\end{array}$ & $\begin{array}{l}5 \mathrm{~cm} \text { interrow distance } \\
\text { Corn \& soybean }\end{array}$ & $\begin{array}{l}10 \mathrm{~cm} \text { interrow distance } \\
\text { Corn \& soybean }\end{array}$ \\
\hline Corn stalk DMY (ton/ha) & $5.9 \pm 0.4^{\mathrm{a}}$ & $5.1 \pm 0.4^{\mathrm{a}}$ & $6.3 \pm 0.6^{\mathrm{a}}$ & $5.5 \pm 0.5^{\mathrm{a}}$ \\
Corn ear DMY (ton/ha) & $6.6 \pm 0.5^{\mathrm{a}}$ & $4.8 \pm 0.6^{\mathrm{b}}$ & $7.2 \pm 0.03^{\mathrm{a}}$ & $6.7 \pm 0.4^{\mathrm{a}}$ \\
Soybean DMY (ton/ha) & - & $0.8 \pm 0.1^{\mathrm{a}}$ & $0.7 \pm 0.3^{\mathrm{a}}$ & $0.9 \pm 0.2^{\mathrm{a}}$ \\
Total DMY (ton/ha) & $12.5 \pm 0.9^{\mathrm{ab}}$ & $10.7 \pm 0.7^{\mathrm{b}}$ & $14.2 \pm 0.3^{\mathrm{a}}$ & $13.1 \pm 1.03^{\mathrm{ab}}$ \\
\hline
\end{tabular}

a, bVariables having varying superscript in the same row are different $(P<0.05)$, SE Standard error, DMY Dry matter yield 


\section{Corn TDN yield}

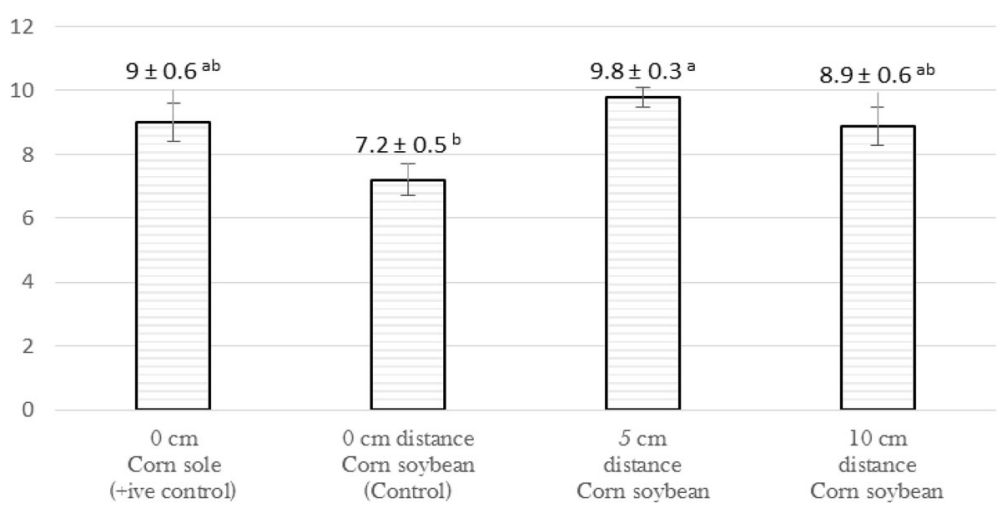

Fig. 2 Effect of different interrow distance between corn and soybean on total digestible nutrient in intercropping corn forage (Mean \pm SE). *Bar variable with value over top having different superscripts are different $(P<0.05)$

Maize growth could be highly sensitive to spatial arrangement [27] and interplant competition might affect growth of neighboring plants negatively [28]. Although comparative data between $5 \mathrm{~cm}$ and $10 \mathrm{~cm}$ distance treatments showed non-significant difference but distinct higher tendency in corn stalk height, corn stalk DMY and corn ear DMY and even total mixed forage DMY under $5 \mathrm{~cm}$ distance treatment might be due to factor that $5 \mathrm{~cm}$ distance could be optimum space between corn and soybean seeding lines than wider interrow space of $10 \mathrm{~cm}$ in this study.

In contrast to previous published literature, growth performance of plants in this study should also be decreased significantly at zero $\mathrm{cm}$ inter-row distance due to intensified interplant competition. However, growth parameters were not significantly $(P>0.05)$ different among various inter-seed spaces between corn and soybean due to larger variation in data. Anyhow, average corn ear height was tended to decrease at zero $\mathrm{cm}$ interrow distance, although it was not significantly different from other treatments. This might be considerable limitation of this study and needs further research to be conducted for authentication of adequate interrow space between in corn soybean intercropping.

\section{Conclusion}

Conclusively, pattern of corn and soybean seeding in rows at $5 \mathrm{~cm}$ interrow distance was found suitable which provided adequate interplant space to maintain enough mutual cooperation and decreased competition between both species for optimum production performance and nutritive value of intercropped forage.

\section{Abbreviations}

Bean, Soybean and DMY: Dry matter yield; DM: Dry matter; NPK: Nitrogen phosphorus potassium; SAS: Statistical analysis system; SE: Standard error; TDN: Total digestible nutrients; Temp: Temperature

\section{Acknowledgements}

Not applicable.

\section{Funding}

The work was supported by IPET agricultural life industry technical development project (314024-3).

\section{Availability of data and materials}

Dataset generated or analyzed during the course of study are not publicly available due property of research project funded by IPET agricultural life industry technical development. However, it can be available from corresponding author on reasonable request.

\section{Authors' contributions}

CHK designed plan of study and supervised the research trial, whereas MF analyzed collected data and wrote the manuscript. JTK was principal author who was responsible to manage all activities of the experiment, whereas YS and DK worked in the execution of trial and also involved in data collection and interpretation. All authors read and approved the final manuscript.

Ethics approval and consent to participate

Not applicable.

\section{Consent for publication}

Not applicable.

\section{Competing interests}

The authors declare that they have no competing interests.

\section{Publisher's Note}

Springer Nature remains neutral with regard to jurisdictional claims in published maps and institutional affiliations.

\section{Author details}

${ }^{1}$ Department of Animal Science, Kyungpook National University, 2559, Gyeongsang-daero, Sangj-si 37224, South Korea. ${ }^{2}$ Department of Livestock Production and Management, Arid Agriculture University, Rawalpindi 46300, Pakistan.

Received: 28 May 2017 Accepted: 6 November 2017

Published online: 05 February 2018

\section{References}

1. Kim B, Han S, Kim T, Yang H. Agriculture, farm villages and prospect of food industry. Korea: Korean Rural Economic Institute (KREI); 2012.

2. Chung SH, Lee JS, Kim MJ, Lee HG. The development status and prospect of Korean livestock industry. J Anim Vet Advan. 2014;13(20):1143-9. 
3. Korean Statistics (KOSTAT). Agriculture area survey in 2016 (According to Remote Sensing), the statistics Korea, Ministry of strategy and finance, Republic of Korea. 2016. http://kostat.go.kr/portal/eng/surveyOutline/1/1/ index.static. Accessed 15 Oct 2016.

4. Dado RG. Nutritional benefit of specialty maize grain hybrid in dairy diets. J Anim Sci. 1999:197-207.

5. Yadav MR, Kumar R, Ram H. Using quality protein maize as an elite feed and fodder for. Livestock. 2016; https://www.researchgate.net/publication/ 308899920. Accessed 15 Oct 2016

6. Gebrehiwot L, McGrow RL, Assefu G. Forage yield and quality profile of three annual legumes in the tropical highlands of Ethiopia. Trop Agric. 1996; 73:83-98.

7. Seo JD, Chae JH, Park JH, Kim MS, Kwon CH, Lee JD. Yield and quality of forage produced by mixed planting of soybean and corn. Curr res on Agri. Life Sci. 2014;32:105-9.

8. Seran TH, Brintha T. Review on maize based intercropping. J Agron. 2010; 9(3):135-45.

9. Latati M, Pansu M, Drevon JJ, Ounane SM. Advantage of intercropping maize (Zea mays L.) and common bean (Phaseolus vulgaris L.) on yield and nitrogen uptake in Northeast Algeria. Int. J Res App Sci. 2013;01:23-9.

10. Adu-Gyamfi JJ, Myaka FA, Sakal WD, Odgaard R, Vesterager JM, HoghJensen $\mathrm{H}$. Biological nitrogen fixation and nitrogen and phosphorus budgets in farmer-managed intercrops of maize pigeon pea in semiarid southern and eastern Africa. Plant Soil. 2007;295:127-36.

11. Banik P, Sharma RC. Yield and resource utilization efficiency in baby cornlegume intercropping system in the eastern plateau of India. J Sust Agr. 2009;33:379-95.

12. Li L, Zhang FS, Li XL, Christie P, Sun JH, Yang SC, Tang C. Interspecific facilitation of nutrient uptake by intercropped maize and faba bean. Nut Cycl in agro. Ecosystems. 2003;65:61-71.

13. Mpairwe DR, Sabiiti EN, Ummuna NN, Tegegne A, Osuji P. Effect of intercropping cereal crops with forage legumes and source of nutrients on cereal grain yield and fodder dry matter yields. African Crop Sci J. 2002;10:81-97.

14. Addo-Quaye AA, Darkwa AA, Ocloo GK. Yield and productivity of component crops in a maize-soybean intercropping system as affected by time of planting and spatial arrangement. ARPN J of Agric Biol Sci. 2011; 6(9):50-7.

15. Oseni TO, Aliyu IG. Effect of row arrangements on sorghum-cowpea intercrops in the semiarid savannah of Nigeria. Int J Agric Biol. 2010;12(1): 137-40.

16. Holland C, Kezar W, Kautz WP, Lazowski EJ, Mahanna WC, Reinhart R. The pioneer forage manual. Des Moines, IA: A nutritional guide. Pioneer Hi-Bred Int. Inc:; 1990

17. Steel RGR, Torrie JH, Dickey DA. Principles and procedures of statistics. A biochemical approach 3rd ed. NY, USA: McGraw Hill Book Co. Inc; 1997.

18. Farnham DE. Row spacing, plant density and hybrid effects on corn grain yield and moisture. Agron J. 2001;93(5):1049-53.

19. Zhang Y, Liu J, Zhang J, Liu H, Liu S, Zhai L. Row ratios of intercropping maize and soybean can affect agronomic efficiency of the system and subsequent wheat. PLoS One. 2015; https://doi.org/10.1371/journal.pone. 0129245.

20. Prasad RB, Brook RM. Effect of varying maize densities on intercropped maize and soybean in Nepal. Exp Agric. 2005:41:365-82.

21. Keating BA, Carberry PS. Resource capture and use in intercropping: solar radiation. Field Crop Res. 1993;34:273-301.

22. Jiao NY, Zhao C, Ning TY, Hou LT, GZ F, Li ZJ, Chen MC. Effects of maizepeanut intercropping on economic yield and light response of photosynthesis. Chinese. J Appl Ecol. 2008;19:981-5.

23. Verdelli D, Acciaresi HA, Leguizamón ES. Corn and soybean in a strip intercropping system: crop growth rates, radiation interception and grain yield components. Int. J Agron. 2012;12:1-7.

24. Shao-sen L, Yong-jin T. Effects of density, row spacing and hole spacing of maize on intercropped soybean's photosynthetic rates. Soy Sci. 2007;02

25. Latati M, Bargaz A, Belarbi B, Lazali M, Benlahrech S, Tellah S. The intercropping common bean with maize improves the rhizobial efficiency, resource use and grain yield under low phosphorus availability. Eur J Agron. 2016;72:80-90.

26. Yang F, Liao D, Fan F, Gao R, Wu X, Rahman T, Yong T, Liu W, Liu J, Du J, Shu K, Wang $X$, Yang W. Effect of narrow-row planting patterns on crop competitive and economic advantage in maize-soybean relay strip intercropping system. Plant Prod Sci. 2016; https://doi.org/10.1080/ $1343943 \times .2016 .1224553$.
27. Maddonni GA, Otegui ME, Cirilo AG. Plant population density, row spacing and hybrid effects on maize canopy architecture and light attenuation. Field Crops Res. 2001;71:183-93.

28. Franco M, Harper JL. Competition and the formation of spatial pattern in spacing gradients: an example using Kochia Scoparia. J of. Ecol. 1988;76: 959-74.

\section{Submit your next manuscript to BioMed Central and we will help you at every step:}

- We accept pre-submission inquiries

- Our selector tool helps you to find the most relevant journal

- We provide round the clock customer support

- Convenient online submission

- Thorough peer review

- Inclusion in PubMed and all major indexing services

- Maximum visibility for your research

Submit your manuscript at www.biomedcentral.com/submit

) Biomed Central 